\title{
Dispersal ecology of the endangered woodland lichen Lobaria pulmonaria in managed hemiboreal forest landscape
}

\author{
Inga Jüriado • Jaan Liira • Daniela Csencsics • Ivo Widmer • \\ Carole Adolf $\cdot$ Kaupo Kohv $\cdot$ Christoph Scheidegger
}

Received: 13 January 2011/Accepted: 16 April 2011/Published online: 26 April 2011

(C) Springer Science+Business Media B.V. 2011

\begin{abstract}
Changes in the forest management practices have strongly influenced the distribution of species inhabiting old-growth forests. The epiphytic woodland lichen Lobaria pulmonaria is frequently used as a model species to study the factors affecting the population biology of lichens. We sampled 252 L. pulmonaria individuals from 12 populations representing three woodland types differing in their ecological continuity and management intensity in Estonia. We used eight mycobiont-specific microsatellite loci to quantify genetic diversity among the populations. We calculated the Sørensen distance to estimate genetic dissimilarity among individuals within populations. We revealed that L. pulmonaria populations have significantly higher genetic diversity in old-growth forests than in managed forests and wooded meadows. We detected a significant woodland-typespecific pattern of genetic dissimilarity among neighbouring L. pulmonaria individuals, which suggests that in wooded meadows and managed forests dominating is vegetative reproduction. The vegetative dispersal distance between the host trees of $L$. pulmonaria was found to be only $15-30 \mathrm{~m}$. Genetic dissimilarity among individuals was also dependent on tree species and trunk diameter. Lobaria pulmonaria populations in managed forests included less juveniles compared to old-growth forests and wooded meadows, indicating that forest management influences life stage structure within populations. We conclude that as intensive stand management reduces the genetic diversity of threatened species in woodland habitats, particular attention should be paid to the preservation of remnant populations in old-growth habitats. Within managed habitats, conservation management should target on maintenance of the stand's structural diversity and availability of potential host trees.
\end{abstract}

I. Jüriado $(\bowtie) \cdot$ J. Liira $\cdot$ K. Kohv

Institute of Ecology and Earth Sciences, University of Tartu, Lai 40, 51005 Tartu, Estonia e-mail: inga.juriado@ut.ee

I. Jüriado - D. Csencsics - I. Widmer - C. Adolf · C. Scheidegger

WSL Swiss Federal Research Institute, Zürcherstrasse 111, 8903 Birmensdorf, Switzerland

K. Kohv

Estonian Fond for Nature, Magasini 3, 51005 Tartu, Estonia 
Keywords Genetic dissimilarity - Genetic distance - Epiphytic lichen - Microsatellites · Managed forest · Old-growth forest · Population genetics · Wooded meadow

\author{
Abbreviations \\ NE Northeast \\ SW Southwest
}

\title{
Introduction
}

Changes in the forest landscape and management practices have strongly influenced biodiversity, both in terms of species richness and population size of species. Lichenized fungi, especially the species confined to old-growth forests, are among the most affected groups of organisms, reacting even to small changes in their habitat structure such as tree species composition, age distribution of trees and availability of critical microhabitats (Richardson and Cameron 2004). As the epiphytic lichen Lobaria pulmonaria is a conspicuous and well known lichen susceptible to changes in forest habitats, it has served as a model species to study the population biology of lichens at the stand and landscape levels (Scheidegger and Werth 2009). This lichen has also been widely used as an indicator species of undisturbed forest ecosystems and forest areas of high ecological continuity (Rose 1976; Andersson and Appelqvist 1987; Nilsson et al. 1995; Andersson et al. 2003; Campbell and Fredeen 2004; Liira and Sepp 2009). Furthermore, as the species associates with a variety of other rare or endangered lichens, it can be considered as an umbrella species (Scheidegger and Werth 2009; Nascimbene et al. 2010).

Only recently, several studies have dealt with the effects of forest history and woodland type on the distribution or abundance of L. pulmonaria ( $\mathrm{Gu}$ et al. 2001; Nascimbene et al. 2006; Belinchón et al. 2009; Jüriado and Liira 2009, 2010). Within the distribution range of L. pulmonaria in boreal, temperate, montane and oceanic areas in the northern hemisphere and in afrotemperate forests in Eastern and Southern Africa the species occurs in various forest types (Yoshimura 1998) as well as in semi-natural woodlands with a sparse cover of trees (pasture-woodlands, parklands and wooded meadows) (Wolseley and James 2000; Jüriado and Liira 2009). It has been suggested that due to air pollution and intensified forest management practice the area of occupancy of L. pulmonaria has tremendously declined in most parts of Europe (James et al. 1977; Wolseley and James 2000). In Estonia, for example, according to Jüriado and Liira (2009), of the localities of L. pulmonaria $77 \%$ have been recorded from small forest fragments or from larger managed forests, which are prone to further isolation or degradation. Since 2002, at least $19 \%$ of the L. pulmonaria localities in Estonia were threatened due to the strong edge effect and fragmentation of the stands and $6 \%$ of L. pulmonaria localities were destroyed by clear cutting of stands (Jüriado and Liira 2010).

Studies of ecological processes affecting population structure and pattern have profited from the concepts of population and conservation genetics (Scheidegger and Werth 2009; Werth 2010b). The genetic diversity of a lichen population may depend on exogenous factors, such as habitat disturbances and habitat configuration in a landscape (Wagner et al. 2006; Werth et al. 2006b, 2007), or mean diameter of host trees (Otálora et al. 2011). Based on the population genetic studies, Werth et al. (2007) have also suggested that dispersal of L. pulmonaria could be more effective than considered earlier (Scheidegger 
1995; Walser 2004). However, unfavourable ecological conditions in a stand or poor substrate conditions related to host trees may hinder successful establishment and colonization of L. pulmonaria (Werth et al. 2006a). For example, the density of large-diameter host trees within the stand and stand closure (Gu et al. 2001; Öckinger et al. 2005; Jüriado and Liira 2009), extent of the bryophyte cover on the tree bole (Scheidegger et al. 1995; Öckinger et al. 2005) and bark pH of the host tree (Gauslaa 1985) are important ecological drivers that influence establishment and distribution of L. pulmonaria. The herbivory of lichen-feeding molluscs also plays an important role during the establishment process of L. pulmonaria (Asplund and Gauslaa 2008).

Historical changes of the woodland landscapes in Estonia have possibly influenced the population structure and genetic patterns of lichens. This can be expected as the effects of bottlenecks and genetic drift have coincided with habitat loss and fragmentation (Frankham et al. 2002). Firstly, we hypothesize that the genetic diversity of L. pulmonaria populations is dependent on the long-term management type of woodland and present stand structure (canopy cover, stand age, tree diameter and tree species composition). We assessed the effects of these factors on the genetic diversity of L. pulmonaria populations in three woodland types (old-growth forest, managed forests and wooded meadows). Secondly, we hypothesize that genetic dissimilarity among individuals of L. pulmonaria within the stands of the three woodland types is influenced by host tree species, diameter of host trees and between-tree distance due to the limited dispersal ability of lichen propagules. Thirdly, we expect that the regeneration and dispersal limitation of L. pulmonaria is reflected also in the frequency pattern of the developmental stages of its individuals in these stands.

\section{Materials and methods}

\section{Study species}

The life-cycle of $L$. pulmonaria takes on average 35 years. L. pulmonaria reproduces either sexually by means of ascospores, or asexually by vegetative diaspores (soredia, isidioid soredia) or thallus fragments (Scheidegger et al. 1998; Scheidegger and Goward 2002). The soredia are powdery propagules composed of fungal hyphae wrapped around a few green alga cells and, in the case of L. pulmonaria, they may remain attached in the soralia (formation place of soredia) and develop into isidioid soredia, which are covered by an outer layer of hyphae (cortex) (Büdel and Scheidegger 2008). Dispersal by vegetative propagules predominates at the local scale (Walser 2004; Werth et al. 2006a, b), while ascospores are more important for long-distance dispersal (Wagner et al. 2006; Werth et al. 2007).

\section{Study area}

The vegetation of Estonia belongs to the hemiboreal sub-zone of the southern part of the boreal forest zone (Laasimer and Masing 1995). In historical times, approximately $85 \%$ of the Estonian land area was covered by forest, while the increasing human impact has reduced the proportion of forest, especially since the eighteenth century (Laasimer 1965). The forest cover was at its minimum (less than $20 \%$ of the land area) in the first decades of the twentieth century and has increased since reaching a proportion of $52 \%$ of the land area (Adermann 2008). 
Therefore, a large part of present-day forests in areas of former grasslands, agricultural lands and drained mires represents secondary forests (Etverk and Sein 1995). In some regions, present-day forests have developed from wooded meadows, which were widespread traditional, semi-natural ecosystems until the mid-twentieth century (Kukk and Kull 1997). Wooded meadows used to consist of regularly mown open glades and scattered shrubs and solitary trees, often oak trees that were hundreds of years old. For ecological and historical reasons (Päretel et al. 2007), these semi-natural man-made habitats have very high diversity of species from different groups of organisms (Kukk and Kull 1997), including lichens (Leppik and Jüriado 2008; Leppik et al. 2011). After the rapid increase in intensive agriculture and collectivisation of farmland in Estonia in the second half of the twentieth century, mosaic wooded meadows were replaced by cultivated fields, or became overgrown with deciduous or mixed forests. Only a minority $(0.2 \%)$ of the area of wooded meadows with a semi-opened woodland structure has been preserved to this day (Kukk and Sammul 2006).

\section{Field sampling}

Lobaria pulmonaria occurs mainly in northeastern (NE) and southwestern (SW) Estonia (Jüriado and Liira 2009, 2010) where is also found the highest spatial and historical forest continuity (Laasimer and Masing 1995). We chose 12 L. pulmonaria populations, six from NE and six from SW Estonia (Table 1). Three habitat types were defined: old-growth forests, managed forests and wooded meadows. Old-growth forests were defined as unmanaged stands where the age of dominating trees is 120-190 years (database of the State Forest Management Centre). These forest stands were mixed forests with Populus tremula and other deciduous trees, or they were dominated by coniferous trees as Picea abies. The stands had a near-natural forest structure according to Kohv and Liira (2005). Moderately managed forests were dominated by Betula pendula or B. pubescens, Fraxinus excelsior, Ulmus glabra, with an average age of dominating trees of less than 100 years. The host trees of L. pulmonaria in these stands, however, were generally older and had been preserved during the last management cycles of selective logging. The management of the three wooded meadows from where L. pulmonaria was sampled ceased around 50 years ago. In these partially overgrown wooded meadows grew many deciduous tree species as Qurecus robur, Acer platanoides, Betula, P. tremula, Salix caprea, Tilia cor$d a t a$, and some coniferous tree species as $P$. abies; the oldest oak trees $(Q$. robur) being 400 years old.

The centre of each study population was selected by identifying the position of trees exhibiting the highest density of $L$. pulmonaria individuals within the study stand, e.g. forest compartment with homogenous stand structure. In smaller populations, all colonized trees within the forest compartment were sampled; in larger populations colonized trees in the vicinity of the centre were sampled, thus collecting up to 27 specimens (Table 1), which follows the suggested sample size per population (Werth 2010a). To avoid damaging the populations, only a small sample per specimen was nipped off with the scissors. In total, 252 L. pulmonaria samples were collected from 12 populations. The height from the ground of each sampled L. pulmonaria individual on the tree trunk was measured (individuals at a height of up to $2.5 \mathrm{~m}$ from the ground were sampled) and presence of fruit bodies (apothecia) on each thallus was recorded (generative specimens). Lichen thalli without soralia and isidia were defined as juveniles. The distance and azimuth of each sampled tree to the central point was measured and the diameter was recorded at breast 


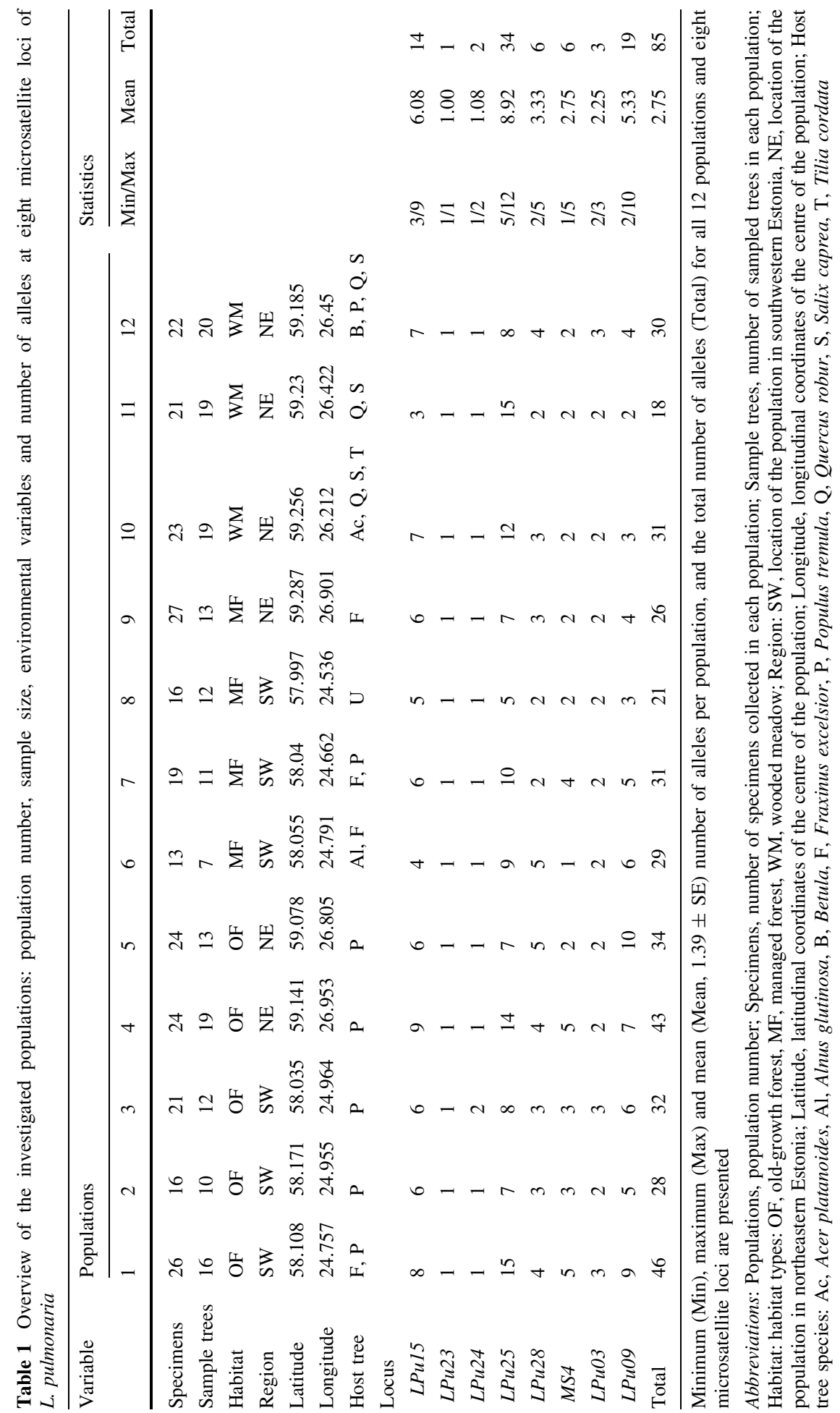


height $(1.3 \mathrm{~m})$. The tree canopy cover was estimated near each sampled tree trunk (increasing openness on a scale from 1 to 4 ) and averaged per stand.

\section{Molecular methods}

Approximately $50 \mathrm{mg}$ of each lichen thallus were lyophilized overnight and ground in a mixer mill (Retsch MM2000) for $5 \mathrm{~min}$ at $30 \mathrm{~Hz}$. The DNA was extracted with the Qiagen DNeasy 96 Plant Kit according to the manufacturer's protocol, except of adding $600 \mu \mathrm{l}$ instead of $400 \mu \mathrm{l}$ of buffer AP1. Eight fungus specific microsatellite loci were used (LPu03, LPu09, LPu15, LPu23, LPu24, LPu25, LPu28, MS4; Walser et al. 2003, 2004; Widmer et al. 2010), which were amplified following the protocol presented by Widmer et al. (2010). The fragment lengths of PCR products were determined using a 3730 DNA Analyzer and a 3130 Genetic Analyzer (Applied Biosystems, Foster City, CA) with LIZ-500 and ROX-500, respectively as the internal size standards and the electropherograms were analysed with the GeneMapper ${ }^{\mathrm{TM}} \mathrm{v} 3.7$ software.

\section{Statistical analyses}

Allele frequency per locus and genetic diversity per population $(H)$ were calculated in GenAlEx ver. 6.2 (Peakall and Smouse 2005). The number of distinct multilocus genotypes was estimated with GenClone 2.0 (Arnaud-Haond and Belkhir 2007).

Ggeneral regression model (GRM) analysis (implemented in the program package Statistica 8.1; Statsoft Inc. 2005) with the stepwise selection procedure was applied to study the relationship between genetic diversity and characteristics of stands. Each population was characterized by the following explanatory variables: (1) region (NE or SW Estonia), (2) habitat type (old-growth forest, managed forest or wooded meadow), (3) stand age (mean age of the oldest trees in stand, values log-transformed), (4) DBH (mean diameter of the host trees measured at a height of $1.3 \mathrm{~m}$ above the ground), (5) variation coefficient of DBH of the host trees per population, (6) number of host tree species per population, (7) canopy cover calculated as average per stand, and (8) log-transformed sample size. In the model, the interaction effect between woodland habitat type and region was also tested.

Based on the occurrence (presence-absence data) of alleles in eight microsatellite loci, the Sørensen distance of genetic dissimilarity between all individuals within every population was calculated using the program package PC-ORD version 4.25 (McCune and Mefford 1999). The Sørensen distance belongs to the family of dissimilarity measures of Dice, Hellinger and Bray Curtis. The Sørensen distance was used to estimate genetic dissimilarity as it attaches less weight to absences (0) in the data matrix of alleles and loci in the case of a large proportion of 0's in that matrix. Using GRM in Statistica 8.1 (Statsoft Inc. 2005), we analysed the descriptive power of several factors (between-tree distance; difference in trunk diameter; effect of tree species in a pair of neighbouring trees: same $-1 /$ different -0 ) in interaction with woodland habitat type for genetic dissimilarity distance among specimens within populations. The between-tree distance was transformed into class estimates based on the log-transformed distances between the trees for a pair of neighbouring trees used for comparison. The difference in trunk diameter between neighbouring trees was defined to be different in ecological sense in case the difference in diameter among the trees exceeded $25 \%$. Such a diameter threshold is based on the generalized knowledge gained from other studies (Riiali et al. 2001; Öckinger et al. 2005; Belinchón et al. 2009). 
We analysed the occurrence probability of juveniles and generative specimens in the populations, using generalized linear models (GLIM, Binomial error distribution and logit link-function), in the three woodland habitat types (variable 'Habitat') and the dependence of this occurrence probability on light availability (variable 'Canopy cover'), host tree DBH and height of the individuals, applying the stepwise forward or backward selection procedure implemented in the program package Statistica 8.1 (StatSoft Inc 2005).

\section{Results}

Genetic variation of L. pulmonaria in Estonia

In total, we found 85 alleles at eight microsatellite loci, which yielded 153 multilocus genotypes. Allele size distribution per locus ranged from 142 bp in locus LPu15 to $902 \mathrm{bp}$ in locus $L P u 09$. All studied microsatellite loci were polymorphic, except for LPu23 in which the allele of $312 \mathrm{bp}$ was fixed in all populations. For the other loci, the minimum number of alleles was two ( $L P u 24)$, and the maximum number was 34 (LPu25). The number of alleles per population was very similar in both regions, varying from 18 to 43 in $\mathrm{NE}$, and from 21 to 46 in SW (Table 1), the number of private alleles per region was also similar and included 20 alleles in NE and 23 in SE. The mean number of alleles per locus across all 12 populations ranged from 1.00 to 8.92 .

Genetic diversity of L. pulmonaria in relation to stand parameters

The GRM analysis showed that the genetic diversity of $L$. pulmonaria populations varied among the woodland habitat types. The genetic diversity $(H)$ was significantly higher in old-growth forests $(H=0.471)$ than in managed forests and wooded meadows $(0.358$ and 0.317 , respectively) (Table 2 ). The genetic diversity of $L$. pulmonaria populations was positively correlated with stand age (logarithmically, 'lgStand age' in Table 2). However, as indicated by the significant interaction term between 'Habitat' and 'IgStand age'

Table 2 The results of general regression model analysis (GRM) for the genetic diversity of L. pulmonaria populations

\begin{tabular}{llrllr}
\hline Effect & df & $F$ & $P$ & Mean $( \pm$ SE $)$ & Slope \\
\hline Intercept & $1 ; 5$ & 6.2 & 0.047 & & -0.673 \\
Habitat & $2 ; 5$ & 11.7 & $\mathbf{0 . 0 0 8}$ & & \\
$\quad$ Old-growth forest & & & & $0.471 \pm 0.015^{\mathrm{b}}$ & $0.358 \pm 0.014^{\mathrm{a}}$ \\
Managed forest & & & & $0.317 \pm 0.095^{\mathrm{a}}$ & 0.449 \\
Wooded meadow & $1 ; 5$ & 12.2 & $\mathbf{0 . 0 1 3}$ & & \\
lgStand age & $2 ; 5$ & 8.2 & $\mathbf{0 . 0 1 9}$ & & \\
lgStand age*Habitat & & & & \\
\hline
\end{tabular}

Slope estimates are presented for continuous variables; within-group average values are presented for categorical variables, letter labels denote homogeneity groups according to the results of Tukey-Kramer multiple comparison test

$d f$ degrees of freedom, $F$ F-criterion value, $P$ significance level, Slope slope of the regression line

Statistically significant $P$-values are in bold 


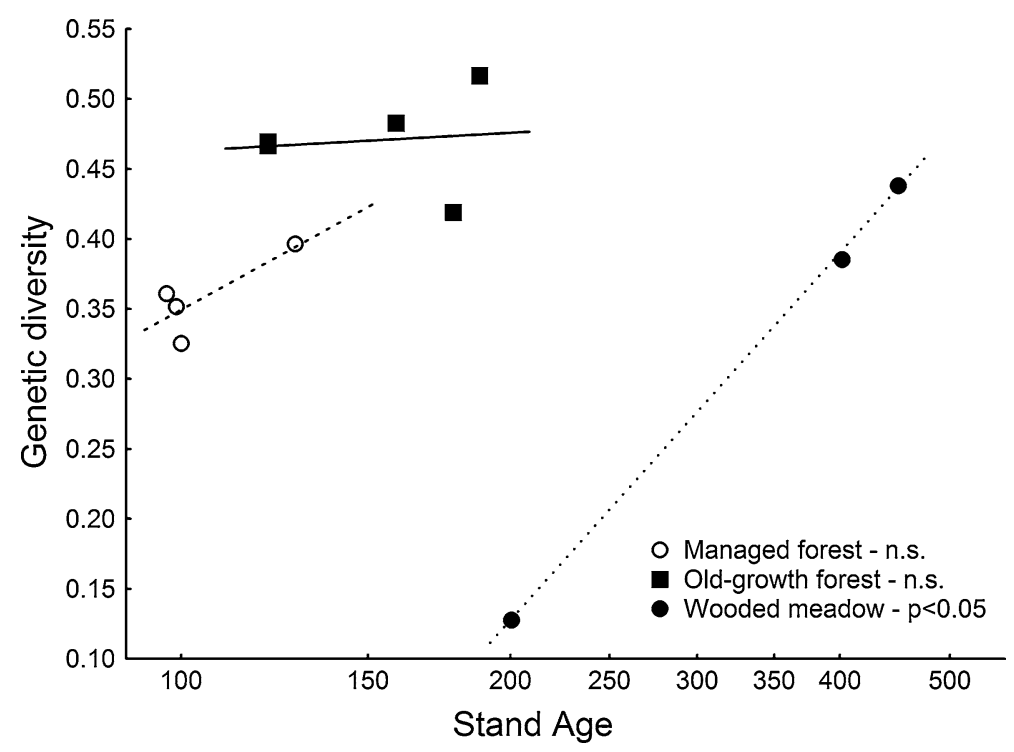

Fig. 1 Relationship between the genetic diversity of L. pulmonaria and stand age in three habitat types. Significance test for the slope estimates different from zero: ${ }^{*} P<0.05$; ns not significant

(Table 2), this relationship was statistically significant only for wooded meadows, although a similar positive trend can be observed also for managed forests (Fig. 1).

Genetic dissimilarity of L. pulmonaria individuals

The analysis of the Sørensen distance of genetic dissimilarity among L. pulmonaria individuals within each population revealed significant habitat-specific genetic dissimilarity patterns. However, as we suggested in our second hypothesis, these patterns could be dependent on between-tree-distance classes, tree species, and tree diameter class (Table 3). Host trees from the same species reduced genetic dissimilarity among L. pulmonaria individuals but this was only evident for managed forests and wooded meadows (Fig. 2).

Table 3 The results of general regression model analysis (GRM) for the Sørensen distance of genetic dissimilarity among individuals in each L. pulmonaria population

\begin{tabular}{llcc}
\hline Effect & df & $F$ & $P$ \\
\hline Region & $1 ; 26$ & 2.6 & 0.106 \\
Habitat type & $2 ; 26$ & 3.0 & 0.079 \\
Different tree species & $1 ; 26$ & 0.7 & 0.384 \\
Different DBH classes & $1 ; 26$ & 0.6 & 0.422 \\
Distance classes & $5 ; 26$ & 47.0 & $<\mathbf{0 . 0 0 0 1}$ \\
Different tree species * Habitat & $2 ; 26$ & 18.4 & $<\mathbf{0 . 0 0 0 1}$ \\
Different DBH classes * Habitat & $2 ; 26$ & 6.4 & $\mathbf{0 . 0 1 5}$ \\
Distance classes * Habitat & $11 ; 26$ & 15.0 & $<\mathbf{0 . 0 0 0 1}$ \\
\hline
\end{tabular}

$d f$ degrees of freedom, $F$ F-criterion value, $P$ significance level

Statistically significant $P$-values are in bold 


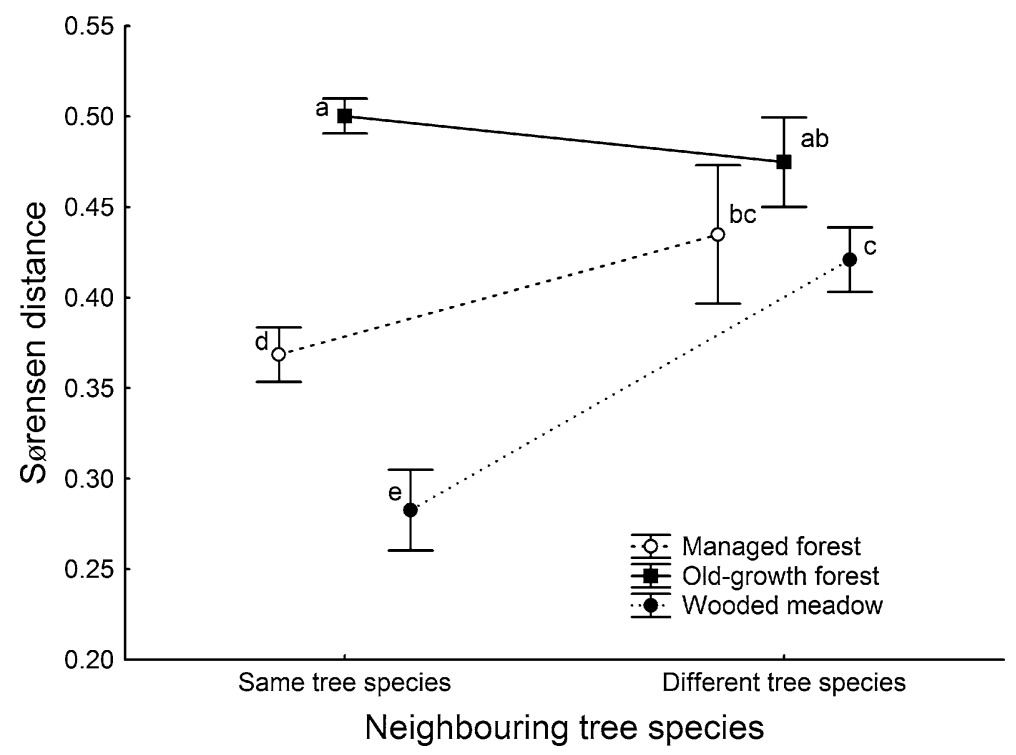

Fig. 2 Sørensen distance of genetic dissimilarity of L. pulmonaria individuals on the same versus different host tree species (class variable with two levels on the $\mathrm{X}$-axis), presented separately for three habitat types. Letter labels denote homogeneity groups according to the results of Fisher LSD multiple comparison test

In these woodland types, the Sørensen distance was significantly smaller between L. pulmonaria individuals growing on the same host tree species compared to individuals growing on different tree species (Fig. 2). A particularly low genetic dissimilarity among individuals on the same tree species was observed in wooded meadows. In contrast, in populations located in old-growth forests, the Sørensen distance was constantly large among L. pulmonaria individuals growing either on the same host tree or on different host trees (Fig. 2).

In addition to the effect of host tree species identity, we found the habitat-type-specific effect of diameter difference of the neighbouring trees on genetic dissimilarity. The Sørensen distance of genetic dissimilarity among L. pulmonaria individuals did not depend on the diameter of the neighbouring trees in old-growth and in managed forests (Fig. 3). Yet it should be noted that genetic dissimilarity was significantly lower in managed forests than in old-growth forests. In wooded meadows, however, the genetic dissimilarity among individuals on the host trees of different diameter classes was significantly lower than on neighbouring trees with a similar diameter (Fig. 3).

Finally, we found also strong relationship of genetic dissimilarity with geographic distance between the host trees within a habitat (Table 3), but the significant interaction term between distance class and habitat type indicates habitat-specific relationship between Sørensen distance and geographic distance (Table 3). The Sørensen distance of genetic dissimilarity among L. pulmonaria individuals found on one tree trunk (distance class $=0$ ) was comparable in all habitat types with an estimate of 0.3 , indicating ca. $70 \%$ of clonality among L. pulmonaria individuals growing on the same tree trunk (Fig. 4). Habitat-type specificity became particularly pronounced for between-tree distances 1-50 m. In oldgrowth forests genetic dissimilarity increased in comparison to within-tree dissimilarity and reached a maximum already when individuals from short distance classes (distance 


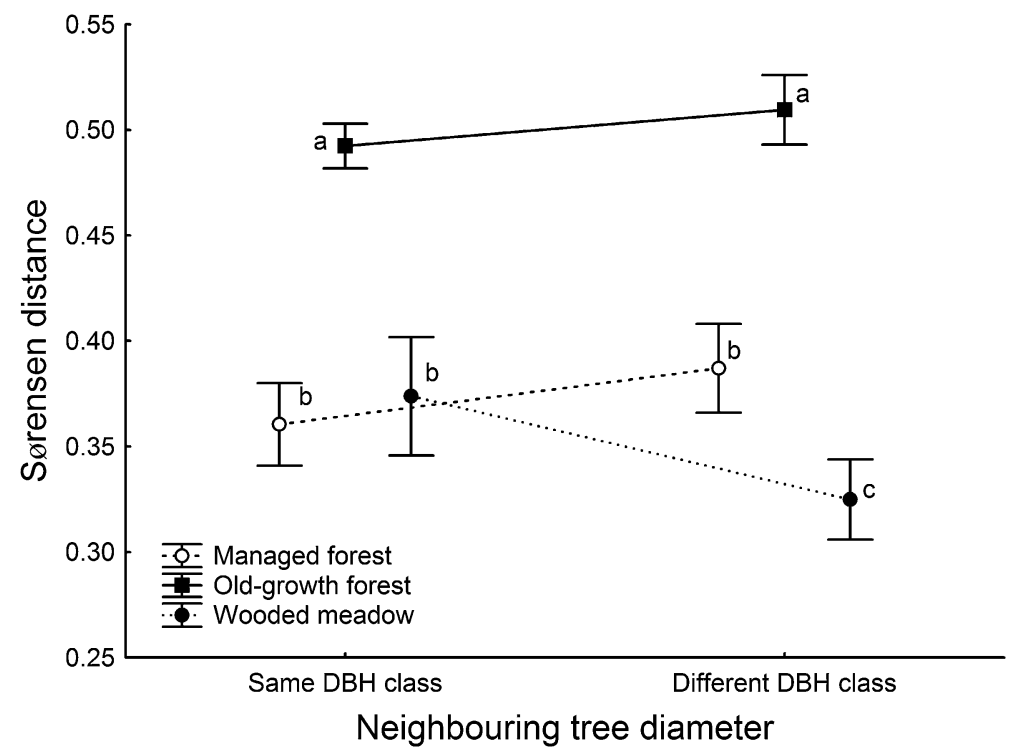

Fig. 3 Sørensen distance of genetic dissimilarity of L. pulmonaria individuals on host trees with the same versus different diameter (DBH) (class variable with two levels on the x-axis), presented separately for three habitat types. Letter labels denote homogeneity groups according to the results of Fisher LSD multiple comparison test

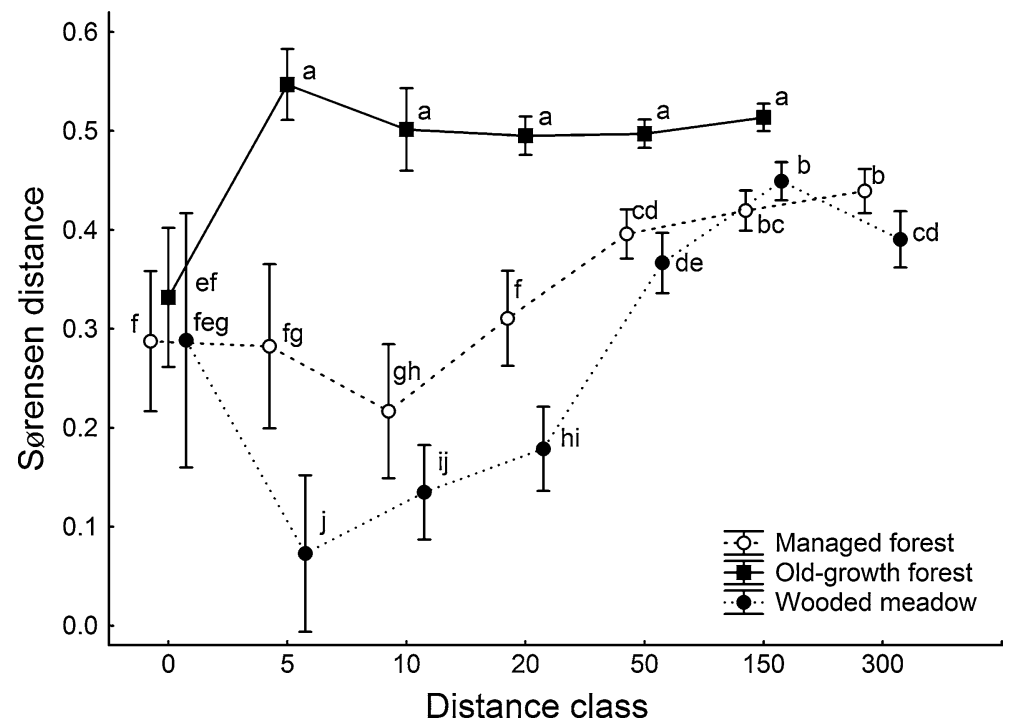

Fig. 4 Sørensen distance of genetic dissimilarity of L. pulmonaria individuals in different distance classes among host trees in three habitat types. Letter labels denote homogeneity groups according to the results of Fisher LSD multiple comparison test

class 1-5 m) were compared (Fig. 4). In wooded meadows, in contrast, the Sørensen distance of genetic dissimilarity among L. pulmonaria individuals on neighbouring trees (distances 1-20 m) was even lower than among individuals growing on the same tree 
trunk; while at larger distances (50-300 m), the Sørensen distances increased over the level of within-tree estimate. However, genetic dissimilarity even among the most distant host trees was lower in wooded meadows than in old-growth forests. For managed forests, the Sørensen distance of genetic dissimilarity had an intermediate pattern along the distance classes, maintaining the level of the within-tree distances up to a distance of $20 \mathrm{~m}$ but, as for wooded meadows, reached a maximum at between-tree distances of 21-50 m (Fig. 4).

The between-tree distance at which the genetic dissimilarity exceeds the within-tree dissimilarity level can be defined as the threshold distance at which sexual reproduction starts to predominate over vegetative reproduction. Accordingly, vegetative dispersal from a small number of $L$. pulmonaria individuals dominated up to ca. $21-50 \mathrm{~m}$ in wooded meadows and managed forests.

Our data set comprised 296 pairs of specimens with a recurrent genotype, i.e. specimens sharing the same multilocus genotype. The mean geographic distance within a pair was $22.7 \mathrm{~m}$, and when specimens on the same tree were excluded, the mean distance was $26.1 \mathrm{~m}$. The maximum distance among the specimens sharing the same multilocus genotype was $301 \mathrm{~m}$, which was observed in population No. 10, one of the wooded meadows in NE Estonia. However, as the geographic distance within a pair had a positively skewed distribution, the use of non-parametric statistics was justified. The median distance was only $13.0 \mathrm{~m}$ (15.0 $\mathrm{m}$ when the same-tree observations were excluded), and $75 \%$ of the observations were made up to a distance of $23.0 \mathrm{~m}(27.0 \mathrm{~m}$ when the same-tree observations were excluded). These results show that use of the measure of mean distance overestimates clonal dispersal ability.

\section{Probability of presence of juvenile and generative specimens of L. pulmonaria}

The proportion of juvenile specimens per population varied from 0 to $38 \%$ (mean 14.9) and the proportion of generative specimens varied from 0 to $21 \%$ per population (mean 6.9). In all studied populations the highest proportion of specimens, bearing soredia and isidia, was observed in the vegetative stage (62-89\% per population, mean 77.8$)$.

The probability of the presence of juveniles in a population depended on the geographic region and habitat type but was also related to growth conditions on individual trees (Table 4). The percentage of juveniles in the populations of SW Estonia was slightly higher $(18.3 \%)$ compared to the populations of NE Estonia (12.6\%). The proportion of juveniles in managed forest populations was significantly lower compared to old-growth forest and wooded meadow populations (Fig. 5). Additionally, frequency of juveniles was positively correlated with increasing height of the L. pulmonaria specimen on a host tree trunk and with increasing canopy cover near the tree (Table 4). The frequency of occurrence of generative specimens only depended on the woodland habitat type. Managed forests showed a significantly higher proportion of generative specimens in a population compared to old-growth forests and wooded meadows (Table 4; Fig. 5).

\section{Discussion}

The major driver of genetic structure among and within Estonian L. pulmonaria populations is the local land-use history of woodland habitats. Compared to managed habitats as wooded meadows and managed forests, only old-growth forests maintain high genetic diversity, as high genetic diversification among individuals was detected already at distances of $5 \mathrm{~m}$ between the host trees. The genetic dissimilarity pattern of L. pulmonaria 
Table 4 The results of generalized linear models (GLIM) analysing the effect of region, habitat type, tree $\mathrm{DBH}$, canopy cover and location height of L. pulmonaria specimens on tree on the occurrence probability of juvenile and generative specimens of L. pulmonaria

\begin{tabular}{|c|c|c|c|c|c|c|c|c|}
\hline \multirow[t]{2}{*}{ Effect } & \multicolumn{4}{|c|}{ Presence of juveniles } & \multicolumn{4}{|c|}{ Presence of generative specimens } \\
\hline & df & $\begin{array}{l}\text { Wald } \\
\text { statistic }\end{array}$ & $P$ & Slope & df & $\begin{array}{l}\text { Wald } \\
\text { statistic }\end{array}$ & $P$ & Slope \\
\hline Intercept & 1 & 10.22 & 0.001 & -10.69 & 1 & 1.22 & 0.269 & -5.01 \\
\hline Region & 1 & 4.412 & $\mathbf{0 . 0 3 5}$ & Estimates in the text & 1 & 0.53 & 0.468 & \\
\hline Habitat & 2 & 12.27 & 0.002 & See Fig. 5 & 2 & 6.30 & 0.042 & See Fig. 5 \\
\hline Mean DBH & 1 & 0.002 & 0.957 & 0.005 & 1 & 1.44 & 0.231 & 1.98 \\
\hline Height of Lobaria & 2 & 7.61 & 0.005 & 2.784 & 1 & 0.01 & 0.905 & 0.18 \\
\hline Canopy cover & 1 & 5.63 & 0.017 & 3.924 & 1 & 1.77 & 0.183 & -2.56 \\
\hline
\end{tabular}

The specifications of the GLIM model are: binomial error distribution, logit link-function and Pearson correction-coefficient for over-dispersion. Slope estimates are presented for continuous variables

$d f$ degrees of freedom, $P$ significance level, Slope slope of the regression line

Statistically significant $P$-values are in bold

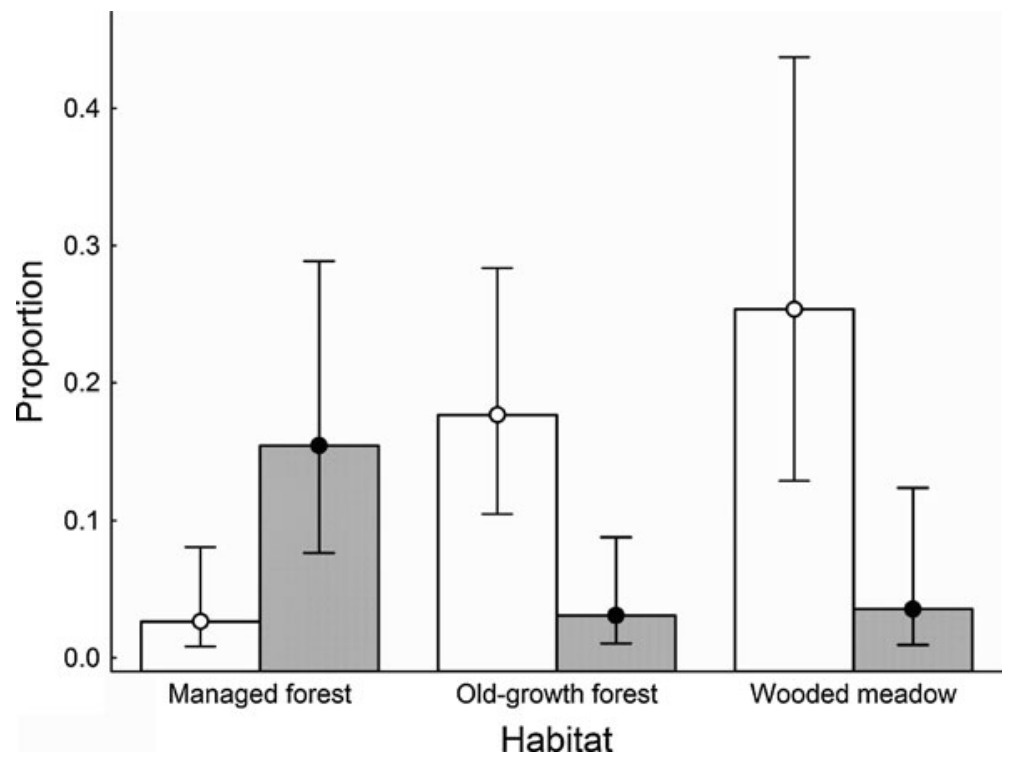

Fig. 5 Probability of presence of juvenile (open bars) and generative (filled bars) specimens of L. pulmonaria in different habitats

individuals suggests that vegetative reproduction and clonal spread dominates in wooded meadows and successional managed forests. Significant diversification among L. pulmonaria individuals in managed forests and wooded meadows started at between-tree distances of $21-50 \mathrm{~m}$ (Fig. 4) as at that distance range the dispersal based on sexual reproduction starts to dominate over vegetative reproduction in these habitat types.

From the methodological point of view, the dispersal distance can be quantified in two different ways (Werth 2010b). The effective dispersal distance of L. pulmonaria is defined as the distance to a safe site, i.e. the trunk of a living tree, which can be substantially 
shorter than the direct dispersal distances estimated from the diaspores caught at ground level, e.g. diaspores sampled from snow on the ground (Werth 2010b). This is explained by the fact that landing of diaspores on the ground (snow covered ground) can occur at a longer distance from the source compared to adhesion at optimal growth height on the tree trunk. Summing up the results of our study, we suggest that the effective vegetative dispersal distance of L. pulmonaria is approx. $15-30 \mathrm{~m}$, which is considerably less than the corresponding figures reported in earlier studies (Kalwij et al. 2005; Öckinger et al. 2005). The estimated lower effective vegetative dispersal ability can only partly be explained by methodological differences and the statistics used. The commonly used arithmetic mean is sensitive to rarely occurring high values, while the median statistic is less dependent on them and thus reduces the overestimation bias. Consequently, we can state that the shortdistance dispersal ability of L. pulmonaria clearly limits its expansion within the local stand and, particularly, dispersal between stands. The necessity to support the perseverance and growth of reduced $L$. pulmonaria populations, suitable host trees should be at a close distance from source trees, the maximum distance among potential host trees should not exceed $30 \mathrm{~m}$.

For the studied wooded meadows, the extremely low estimates of genetic dissimilarity among L. pulmonaria individuals indicate the dominance of the clonal spread of L. pulmonaria from a few remnant oak trees to younger trees. Wooded meadows are seminatural habitats whose typical form was established about 2000 years ago as a result of mowing with the scythe (Laasimer 1965; Kukk and Kull 1997). The long-living oak (Quercus robur) was one of the favoured tree species in wooded meadows (Kukk and Kull 1997) and individual oak trees can represent a substrate continuity of several hundred years (in this study approx. 200-400 years). Old trees harbour a higher number of different multilocus genotypes and act as a source of vegetative diaspores. Younger trees between the old ones can be considered sink substrates (Gaggiotti 1996) created only by one or a few colonizations with subsequent clonal spread within the same tree. This idea is supported by genetic diversification among $L$. pulmonaria individuals at between-tree distances of 20-50 m, which reflects the distance pattern of old oak trees in wooded meadows.

The high rate of clonal spread has lead to a high proportion of juvenile individuals in wooded meadows, while the relative frequency of generative (fertile) specimens is still low. Because L. pulmonaria is a heterothallic species (Zoller et al. 1999; Walser et al. 2004), it can be hypothesized that the low overall fertility of L. pulmonaria in overgrown wooded meadows is a consequence of the scarcity of suitable mating types for sexual reproduction. Availability of compatible mating types on a small spatial scale and required habitat quality are both necessary but they are not sufficient prerequisites for formation of apothecia in heterothallic species. Hence conservation of old trees with high genetic diversity is a priority when sexual reproduction of the population is to be favoured.

According to several earlier studies (Gu et al. 2001; Carlsson and Nilsson 2009; Jüriado and Liira 2009), the tree species has also a significant effect on the distribution of L. pulmonaria. However, this effect depends on the land use type. Variation in host tree species affected genetic heterogeneity only in managed habitats such as wooded meadows and managed forests, while this was not observed in old-growth stands. Probably, such a pattern is related to the dominance of one or a few tree species in managed stands. Significant differences in genetic dissimilarity among L. pulmonaria individuals growing on different host tree species within such managed stands indicates the importance of preserving various tree species during the selective cutting of the stands to preserve the genetic diversity of epiphytic lichens. 
In managed forests the proportion of fertile individuals was recorded to be higher than in old-growth forests and wooded meadows. The relatively high frequency of fertile individuals in managed forests is possibly supported by optimal mesoclimatical conditions in a relatively humid forest stand with sufficient light availability, combined with the availability of compatible mating types. High frequency of sexually reproducing individuals could be an indication of an actively growing population but this level can still be insufficient for population recovery as selective cutting has a strong negative impact on the abundance, frequency and fertility of L. pulmonaria (Edman et al. 2008). If we consider also the low establishment success of juveniles in managed forests, those stands probably do not support viable populations of $L$. pulmonaria on a longer time scale.

Woodland management and conservation planning are crucial in the hemiboreal region for long-term maintenance of L. pulmonaria. On the long term, continuing managementinduced local bottlenecks and subsequent genetic drift across a forest landscape can lead to locally reduced genetic diversity and loss of allelic richness on larger geographic scales (Hartl and Clark 1997). To promote the genetic diversity of L. pulmonaria within populations, its fragments could be transplanted from ancient oak trees to younger ones (Scheidegger 1995). Within the habitats of L. pulmonaria populations, conservation management should target on preservation or restoration of adequate light conditions, stand's structural diversity, and availability of potential host trees.

In wooded meadows old trees with $L$. pulmonaria should be preserved as they support higher genetic diversity of L. pulmonaria than younger trees. We do not suggest restoration of the studied overgrown wooded meadows for hay cutting as this will strongly influence the light- and moisture regime of the habitat and, apparently, the population of L. pulmonaria will decline (Gauslaa et al. 2006, Carlsson and Nilsson 2009). Still, to maintain current light conditions in wooded meadows, moderate management is needed, including cutting of some trees to prevent complete overgrowing of the habitat. When thinning the tree or bush layer, conifers should be cut first and the potential host trees of L. pulmonaria should be preserved. Moreover, the potential host tree of $L$. pulmonaria should be in the vicinity (ca. 15-30 m) of ancient trees to increase the possibility that this lichen can colonize a new habitat.

At the landscape level, careful small-scale forest network planning should be performed considering not only the connectivity among habitats or populations but also habitat quality (Otálora et al. 2011). Still, in the long term populations of L. pulmonaria in managed habitats may not be viable as the genetic diversity of the populations of this species depends on old-growth forest landscapes. Even if the remaining old-growth sites are left uncut, population trends of $L$. pulmonaria might still be negative as the species may be subject to an extinction debt since the amount and connectivity of suitable habitats have decreased substantially over the last 150 years (Öckinger and Nilsson 2010). Therefore, first, appropriate conservation measures and management restrictions of old-growth forests and managed stands with $L$. pulmonaria should be implemented without further delay and, second, connectivity among potentially suitable habitats and the existing populations should be improved.

Acknowledgments The authors are thankful to the administration of the Nigula Nature Reserve for kind help during field work. The Genetic Diversity Centre of ETH Zürich (GDC) provided facilities for data collection. We are grateful to Asko Lõhmus and the anonymous reviewers for valuable comments on the manuscript. Ester Jaigma is acknowledged for revising the English text of the manuscript. Financial support was received from the Swiss National Science Foundation (SNF 3100A0-10583 to CS), the Estonian Science Foundation (grants 7878 and 7816), the Ministry of Education and Research of Estonia (targeted financing SF0180012s09 and SF0180153s08), the EEA Financial Mechanism (grant EMP9, 08066N) and the European Union through the European Regional Development Fund (FIBIR Centre of Excellence). 


\section{References}

Adermann V (2008) Estonian forests 2007. The estimation of forest sources by statistical sampling methodology. Metsakaitse- ja Metsauuenduskeskus, Tallinn

Andersson L, Appelqvist T (1987) Lobaria pulmonaria and Gyalecta ulmi as indicators of deciduous woodland with high nature qualities. Svensk Bot Tidskr 81:185-194

Andersson L, Martverk R, Külvik M et al (2003) Woodland key habitat inventory in Estonia 1999-2002. Regio Publishing, Tartu

Arnaud-Haond S, Belkhir K (2007) GENCLONE: a computer program to analyse genotypic data, test for clonality and describe spatial clonal organization. Mol Ecol Notes 7:15-17

Asplund J, Gauslaa Y (2008) Mollusc grazing limits growth and early development of the old forest lichen Lobaria pulmonaria in broadleaved deciduous forests. Oecologia 155:93-99

Belinchón R, Martínez I, Otálora MAG et al (2009) Fragment quality and matrix affect epiphytic performance in a Mediterranean forest landscape. Am J Bot 96:1974-1982

Büdel B, Scheidegger C (2008) Thallus morphology and anatomy. In: Nash TH (ed) Lichen biology. University Press, Cambridge, pp 40-68

Campbell J, Fredeen AL (2004) Lobaria pulmonaria abundance as an indicator of macrolichen diversity in Interior Cedar-Hemlock forests of east-central British Columbia. Can J Bot 82:970-982

Carlsson R, Nilsson K (2009) Status of the red-listed lichen Lobaria pulmonaria on the Alland Islands, SW Finland. Ann Bot Fennici 46:549-554

Edman M, Eriksson A-M, Villard M-A (2008) Effects of selection cutting on the abundance and fertility of indicator lichens Lobaria pulmonaria and Lobaria quercizans. J Appl Ecol 45:26-33

Etverk I, Sein H (1995) Forests and their management. In: Raukas A (ed) Estonian nature. Valgus and Eesti Entsüklopeediakirjastus, Tallinn, pp 402-416

Frankham R, Ballou JD, Briscoe DA (2002) Introduction to conservation genetics. Cambridge University Press, Cambridge

Gaggiotti OE (1996) Population genetic models of source-sink metapopulations. Theor Pop Biol 50:178-208

Gauslaa Y (1985) The ecology of Lobarion pulmonariae and Parmelion caperatae in Quercus dominated forests in south-west Norway. Lichenologist 17:117-140

Gauslaa Y, Lie M, Solhaug KA, Ohlson M (2006) Growth and ecophysiological acclimation of the foliose lichen Lobaria pulmonaria in forests with contrasting light climates. Oecologia 147:406-416

Gu WD, Kuusinen M, Konttinen T et al (2001) Spatial pattern in the occurrence of the lichen Lobaria pulmonaria in managed and virgin boreal forests. Ecography 24:139-150

Hartl DL, Clark AG (1997) Principles of population genetics. Sinauer Associates, Sunderland

James PW, Hawksworth DL, Rose F (1977) Lichen communities in the British Isles: a preliminary conspectus. In: Seaward MRD (ed) Lichen ecology. Academic, London, pp 295-413

Jüriado I, Liira J (2009) Distribution and habitat ecology of the threatened forest lichen Lobaria pulmonaria in Estonia. Folia Cryptog Estonica 46:55-65

Jüriado I, Liira J (2010) Threatened forest lichen Lobaria pulmonaria-its past, present and future in Estonia. For Stud 53:15-24

Kalwij JM, Wagner HH, Scheidegger C (2005) Effects of stand-level disturbance events on the spatial distribution of a lichen indicator of forest conservation value. Ecol Appl 15:2015-2024

Kohv K, Liira J (2005) Anthropogenic disturbances, structural changes and indicators in the boreal forest. Scan J For Res 20:122-134

Kukk T, Kull K (1997) Wooded meadows. Estonia Marit 2:1-249

Kukk T, Sammul M (2006) Area of seminatural Natura 2000 habitat types in Estonia. In: Sammul M (ed) Year-book of the Estonian Naturalists' Society. Estonian Naturalists' Society, Tartu, pp 114-158

Laasimer L (1965) Vegetation of the Estonian S.S.R. Valgus, Tallinn

Laasimer L, Masing V (1995) Flora and plant cover. In: Raukas A (ed) Estonian nature. Valgus and Eesti Entsüklopeediakirjastus, Tallinn, pp 364-401

Leppik E, Jüriado I (2008) Factors important for epiphytic lichen communities in wooded meadows of Estonia. Folia Cryptog Estonica 44:75-87

Leppik E, Jüriado I, Liira J (2011) Changes in stand structure due to the cessation of traditional land use in wooded meadows impoverish epiphytic lichen communities. Lichenologist 43:257-274

Liira J, Sepp T (2009) Indicators of structural and habitat natural quality in boreo-nemoral forests along the management gradient. Ann Bot Fennici 46:308-325

McCune B, Mefford MJ (1999) PC-ORD. Multivariate analysis of ecological data, version 4. MjM Software Design, Gleneden Beach 
Nascimbene J, Caniglia G, Nicli M et al (2006) Populations of Lobaria pulmonaria (L.) Hoffm. in the Cansiglio Regional Forest (Veneto, Pre-Alps, north-east Italy): distribution, diversity and conservation issues. Plant Biosyst 140:34-42

Nascimbene J, Brunialti G, Ravera S et al (2010) Testing Lobaria pulmonaria (L.) Hoffm. as an indicator of lichen conservation importance of Italian forests. Ecol Indicat 10:353-360

Nilsson S, Arup U, Baranowski R et al (1995) Tree-dependent lichens and beetles as indicators in conservation forests. Conserv Biol 9:1208-1215

Öckinger E, Nilsson SG (2010) Local population extinction and vitality of an epiphytic lichen in fragmented old-growth forest. Ecology 91:2100-2109

Öckinger E, Niklasson M, Nilsson SG (2005) Is local distribution of the epiphytic lichen Lobaria pulmonaria limited by dispersal capacity or habitat quality? Biodiv Conserv 14:759-773

Otálora MAG, Martínez I, Belinchón R et al (2011) Remnant fragments preserve genetic diversity of the old forest lichen Lobaria pulmonaria in a fragmented Mediterranean mountain forest. Biodivers Conserv. doi:10.1007/s10531-011-0025-0

Päretel M, Helm A, Roosaluste E, Zobel M (2007) Biological diversity of Estonian semi-natural grassland ecosystems. In: Punning J-M (ed) Problems of contemporary environmental studies, vol 10. Tallinna Ülikooli Ökoloogia Instituut, Tallinn, pp 223-302

Peakall R, Smouse PE (2005) GenAlEx 6: genetic analysis in excel. Population genetic software for teaching and research. The Australian National University, Canberra

Richardson DHS, Cameron RP (2004) Cyanolichens: their response to pollution and possible management strategies for their conservation in northeastern North America. Northeast Nat 11:1-22

Riiali A, Penttinen A, Kuusinen M (2001) Bayesian mapping of lichens growing on trees. Biom J 43:717-736

Rose F (1976) Lichenological indicators of age and environmental continuity in woodlands. In: Brown DH, Hawksworth DL, Bailey RH (eds) Lichenology: progress and problems. Academic, London, pp 279-307

Scheidegger C (1995) Early development of transplanted isidioid soredia of Lobaria pulmonaria in an endangered population. Lichenologist 27:361-374

Scheidegger C, Goward T (2002) Monitoring lichens for conservation: red lists and conservation action plans. In: Nimis PL, Scheidegger C, Wolseley PA (eds) Monitoring with lichens-monitoring lichens, Nato Science Series. IV. Earth and environmental sciences. Kluwer Academic Publishers, Dordrecht, pp 163-181

Scheidegger C, Werth S (2009) Conservation strategies for lichens: insights from population biology. Fungal Biol Rev 23:55-66

Scheidegger C, Frey B, Zoller S (1995) Transplantation of symbiotic propagules and thallus fragments: methods for the conservation of threatened epiphytic lichen populations. Mitteilungen der Eidgenössishen Forschungsanstalt für Wald, Schnee und Landschaft 70:41-62

Scheidegger C, Frey B, Walser J C (1998) Reintroduction and augmentation of populations of the endangered Lobaria pulmonaria: methods and concepts. In: Kondratyuk SJ, Coppins B (eds) Lobarion lichens as indicators of the primeval forests of the Eastern Carpathians (Darwin International Workshop, 25-30 May 1998, Kostrino, Ukraine). Phytosociocentre, Kiev, pp 33-52

StatSoft Inc (2005) Statistica for Windows, ver 8.1. StatSoft, Inc, Tulsa

Wagner HH, Werth S, Kalwij JM et al (2006) Modelling forest recolonization by an epiphytic lichen using a landscape genetic approach. Landsc Ecol 21:849-865

Walser J-C (2004) Molecular evidence for limited dispersal of vegetative propagules in the epiphytic lichen Lobaria pulmonaria. Am J Bot 91:1273-1276

Walser J-C, Sperisen C, Soliva M et al (2003) Fungus-specific microsatellite primers of lichens: application for the assessment of genetic variation on different spatial scales in Lobaria pulmonaria. Fungal Genet Biol 40:72-82

Walser J-C, Gugerli F, Holderegger R et al (2004) Recombination and clonal propagation in different populations of the lichen Lobaria pulmonaria. Heredity 93:322-329

Werth S (2010a) Optimal sample sizes and allelic diversity in studies of the genetic variability of mycobiont and photobiont populations. Lichenologist 43:73-81

Werth S (2010b) Population genetics of lichen-forming fungi-a review. Lichenologist 42:499-519

Werth S, Wagner HH, Gugerli F et al (2006a) Quantifying dispersal and establishment limitation in a population of epiphytic lichen. Ecology 87:2037-2046

Werth S, Wagner HH, Holderegger R et al (2006b) Effect of disturbances on the genetic diversity of an oldforest associated lichen. Mol Ecol 15:911-921

Werth S, Gugerli F, Holderegger R et al (2007) Landscape-level gene flow in Lobaria pulmonaria, an epiphytic lichen. Mol Ecol 16:2807-2815 
Widmer I, Dal Grande F, Cornejo C et al (2010) Highly variable microsatellite markers for the fungal and algal symbionts of the lichen Lobaria pulmonaria and challenges in developing biont-specific molecular markers for fungal associations. Fungal Biol 114:538-544

Wolseley P, James P (2000) Factors affecting changes in species of Lobaria in sites across Britain 1986-1998. For Snow Landsc Res 75:319-338

Yoshimura I (1998) Lung lichens and their vegetation in Japan and the other regions. In: Kondratyuk SJ, Coppins B (eds) Lobarion lichens as indicators of the primeval forests of the Eastern Carpathians (Darwin International Workshop, 25-30 May 1998, Kostrino, Ukraine). Phytosociocentre, Kiev, pp 53-63

Zoller S, Lutzoni F, Scheidegger C (1999) Genetic variation within and among populations of the threatened lichen Lobaria pulmonaria in Switzerland and implications for its conservation. Mol Ecol 8:2049-2059 